\title{
Soluble fractions and kinetics parameters of nitrate and ammonium uptake in sunflower ("Neon" Hybrid) $)^{1}$
}

\author{
Frações solúveis e parâmetros cinéticos de absorção de nitrato e amônio em girassol \\ (Hibrido "Neon")
}

\author{
Luiziene Soares Alves ${ }^{2}$, Carlos Vergara Torres Junior ${ }^{2}$, Manlio Silvestre Fernandes ${ }^{2}$, André Marques dos Santos ${ }^{3 *}$ \\ e Sonia Regina de Souza ${ }^{3}$
}

\begin{abstract}
Sunflower plants are source of oilseeds with great importance for agroenergy. Nitrogen deficiency is considered one of the factors limiting growth and yield. The objective of this study was to assess the nitrogen uptake (high and low supply of nitrate and ammonium) and to determine the uptake kinetics parameters $\left(\mathrm{K}_{m}\right.$ and $\left.\mathrm{V}_{\operatorname{mar}}\right)$ of these ions in sunflower plants (Neon hybrid). The experiment was carried out in a growth chamber using a hydroponic system. The following treatments were applied: 0.2 and $2.0 \mathrm{mmol} \mathrm{L}^{-1}$ of $\mathrm{N}_{-} \mathrm{NO}_{3}{ }^{-}$and $\mathrm{N}_{-} \mathrm{NH}_{4}{ }^{+}$. The two kinetics parameters $\left(K_{m}\right.$ and $\left.V_{\max }\right)$ involved in the uptake of nitrate and ammonium were determined, as well as the soluble fractions $\left(\mathrm{N}^{-\mathrm{NO}_{3}-}\right.$, $\mathrm{N}-\mathrm{NH}_{4}^{+}$, amino-N and sugars) and total $\mathrm{N}$, in different plant tissues. The plants grown with ammonium showed higher $\mathrm{V}_{\max }$ than those cultivated with nitrate. High ammonium rates caused reduction of root volume and the plants supplied with $2.0 \mathrm{mmol} \mathrm{L}{ }^{-1}$ of $\mathrm{N}^{-\mathrm{NO}_{3}}$ - produced more biomass from the roots and aerial part. The highest concentrations of $\mathrm{N}$ $\mathrm{NO}_{3}^{-}$were found in the petioles. Analyzed together, the data suggest a greater potential for use of nitric-N as a nitrogen source for fertilization in the cultivation of sunflower.
\end{abstract}

Key words: Helianthus annuus L.. Oilseed plants. Total N. Nitrogen.

\begin{abstract}
RESUMO - O girassol é uma oleaginosa de grande importância agroenergética e o nitrogênio é considerado um dos fatores limitantes para seu crescimento e produção. O objetivo deste trabalho foi avaliar a absorção de nitrogênio (alto e baixo suprimento de nitrato e amônio) e determinar os parâmetros cinéticos $\left(\mathrm{K}_{m} \mathrm{e} \mathrm{V}_{\max }\right)$ de absorção desses íons em plantas de girassol (híbrido Neon). O experimento foi conduzido em câmara de crescimento utilizando-se sistema hidropônico. Foram aplicados os seguintes tratamentos: 0,2 e 2,0 $\mathrm{mmol} \mathrm{L}^{-1}$ de $\mathrm{N}_{-} \mathrm{NO}_{3}^{-}$e $\mathrm{N}_{-} \mathrm{NH}_{4}^{+}$. Foram determinados os parâmetros cinéticos $\left(K_{m}\right.$ e $\left.V_{\max }\right)$ da absorção de nitrato e amônio, bem como as frações solúveis $\left(\mathrm{N}^{-} \mathrm{NO}_{3}^{-} \cdot \mathrm{N}_{-} \mathrm{NH}_{4}^{+}\right.$, $\mathrm{N}$-amino e açúcares) e $\mathrm{N}$-total em diferentes tecidos das plantas de girassol. As plantas cultivadas com amônio exibiram maior $\mathrm{V}_{\max }$ quando comparadas com as cultivadas com nitrato. Altas doses de amônio provocaram redução no volume radicular e as plantas supridas com 2,0 $\mathrm{mmol} \mathrm{L}^{-1}$ de $\mathrm{N}_{-} \mathrm{NO}_{3}^{-}$produziram maior biomassa de raízes e parte aérea. Os maiores teores de $\mathrm{N}_{-} \mathrm{NO}_{3}^{-}$foram encontrados nos pecíolos. Analisados em conjunto, os dados sugerem maior potencial de utilização de $\mathrm{N}$ nítrico como fonte de nitrogênio para a adubação nitrogenada no cultivo de girassol.
\end{abstract}

Palavras-chave: Helianthus annuus L.. Oleaginosa. N-total. Nitrogênio.

\footnotetext{
DOI: $10.5935 / 1806-6690.20160002$

* Autor para correspondência

${ }^{1}$ Recebido para publicação em 24/10/2014; aprovado em 15/10/2015

Parte da Dissertação de Mestrado da primeira autora apresentada ao Curso de Pós-Graduação em Agronomia - Ciência do Solo - CPGA-CS, Universidade Federal Rural do Rio de Janeiro/UFRRJ

2Departamento de Solos, Universidade Federal Rural do Rio de Janeiro/UFRRJ, Seropédica- RJ, Brasil, luiziene@gmail.com, vergaramaputo93@ gmail.com,manliosf@gmail.com

${ }_{3}^{3}$ Departamento de Química, Universidade Federal Rural do Rio de Janeiro/UFRRJ, Seropédica-RJ, Brasil, amarques@ufrrj.br ou amarques.ufrrj@ gmail.com, soniabq@ufrrj.br
} 


\section{INTRODUCTION}

The sunflower (Helianthus annuus L.) belongs to the family Asteraceae. It is one of the main plant species in the world for production of vegetable oil (FERNÁNDEZMARTÍNEZ; PÉREZ-VICH; VELASCO, 2009). Nitrogen (N) deficiency is one of the main factors limiting the growth and development of plants. For the sunflower, this nutrient is crucial for production of seeds and oil. Various studies have demonstrated that the oil yield can increase or decrease according to the $\mathrm{N}$ dose applied. Zagonel and Mundstock (1991) found that the cultivars tested responded differently to nitrogen fertilization: for the Contisol 711 cultivar, the oil yield decreased at the highest $\mathrm{N}$ rate applied $\left(120 \mathrm{~kg} \mathrm{ha}^{-1}\right)$, while for the DK180 cultivar the effect was the opposite. Rocha (2013) verified that at low $\mathrm{N}$ doses (from 30 to $50 \mathrm{~kg} \mathrm{ha}^{-1}$ ), the BRS324 genotype presented greater oil production, but this declined with higher doses.

Nitrogen can be found in various forms in the soil, but the main forms absorbed by plant roots are nitrate $\left(\mathrm{NO}_{3}^{-}\right)$and ammonium $\left(\mathrm{NH}_{4}^{+}\right)$(MARSCHNER, 2012). The transport of these ions into the cells is carried out by two types of systems, the High Affinity Transport System (HATS), which operates at low nutrient concentrations, and the Low Affinity Transport System (LATS), which operates at concentrations higher than $1 \mathrm{mmol} \mathrm{L}^{-1}$. The high affinity transport system is divided into two subsystems, constitutive (cHATS) and induced (iHATS), activated by low external nutrient concentrations (ASLAM; TRAVIS; HUFFAKER, 1993; OKAMOTO et al., 2006; SIDDIQI et al., 1990). The study of the nutrient absorption kinetics aims to elucidate the roles of these transport systems in the uptake of nutrients by plants. For this purpose, two parameters are used, $\mathrm{V}_{\max }$, which describes the maximum absorption velocity, i.e., when all the transporter sites are loaded; and $\mathrm{K}_{m}$, which describes the affinity of the carrier protein for the nutrient.

Sunflower genotypes can respond differently to nitrogen fertilization (ROCHA, 2013; ZAGONEL; MUNDSTOCK, 1991), so it is important to perform studies to characterize the particularities of the $\mathrm{N}$ uptake system of the different genotypes used to produce seeds and oil. Therefore, the objective of this study was to assess the behavior of the "Neon" sunflower hybrid regarding nitrogen uptake under high and low supply of nitrate and ammonium and to determine the absorption kinetics parameters of these nutrients $\left(\mathrm{K}_{m}\right.$ and $\left.\mathrm{V}_{\text {max }}\right)$.

\section{MATERIAL AND METHODS}

The experiment was conducted in a hydroponic system in a growth chamber of the Soils Department of
Universidade Federal Rural do Rio de Janeiro, located in the city of Seropédica. The plants were submitted to a photoperiod of $14 \mathrm{~h} / 10 \mathrm{~h}$ (light/dark) with luminosity of $500 \mu \mathrm{mol} \mathrm{m}^{-2} \mathrm{~s}^{-1}$ (photosynthetic photon flux), relative air humidity of $50 \%$ and temperature of $28{ }^{\circ} \mathrm{C}$ in the daytime and $26^{\circ} \mathrm{C}$ at night.

Sunflower seeds of the Neon hybrid were germinated in washed and autoclaved sand. Ten days after germination, the plantlets were transferred to pots with capacity of $3.0 \mathrm{~L}$ (two plantlets per pot) and were supplied with $2.8 \mathrm{~L}$ of nutritive solution formulated according to Hoagland and Arnon (1950) at $1 / 4$ of the ionic strength, modified with $1.0 \mathrm{mmol} \mathrm{L}^{-1}$ of $\mathrm{N}^{-N^{-}}{ }_{3}^{-}$and $0.5 \mathrm{mmol} \mathrm{L}^{-1}$ of $\mathrm{N}-\mathrm{NH}_{4}{ }^{+}$. Three days later, the plants were transferred to a solution at $1 / 2$ ionic strength, with the solution exchanged every three days and maintenance of the $\mathrm{pH}$ at 5.8. Thirty days after germination, the plants received a modified Hoagland-Arnon solution without $\mathrm{N}$ for 72 hours. After this period, the treatments were applied, consisting of: 0.2 or $2.0 \mathrm{mmol} \mathrm{L}^{-1}$ of $\mathrm{N}^{-\mathrm{NO}_{3}}$ and 0.2 or $2.0 \mathrm{mmol} \mathrm{L}^{-1}$ of N$\mathrm{NH}_{4}{ }^{+}$. During five hours, samples of the nutritive solution were collected every 30 minutes from all the treatments, after which the samples were collected every 60 minutes

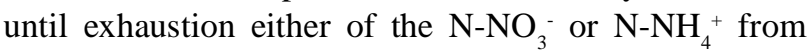
the solution. In the treatments with $0.2 \mathrm{mmol} \mathrm{L}^{-1}$ of $\mathrm{NO}_{3}^{-}$ or $\mathrm{NH}_{4}^{+}, 22$ collections were performed, while in the treatments with $2.0 \mathrm{mmol} \mathrm{L}^{-1}$ of $\mathrm{NO}_{3}^{-}$or $\mathrm{NH}_{4}^{+}$there were 29 collections. At every collection an aliquot of $1 \mathrm{~mL}$ of the solution was taken to measure the concentrations of $\mathrm{N}^{-\mathrm{NH}_{4}}{ }^{+}(\mathrm{FELKER}, 1977)$ and $\mathrm{N}^{-\mathrm{NO}_{3}}{ }_{3}^{-}$(CATALDO et al., 1975) and Miranda, Espey and Wink (2001) with modification: An aliquot of $30 \mu \mathrm{L}$ of sample was mixed with $60 \mu \mathrm{L}$ of Griess reagent (1:1:2), followed by incubation at $40{ }^{\circ} \mathrm{C}$ for 50 minutes. After the addition of $110 \mu \mathrm{L}$ ultrapure water (MilliQ), the spectrophotometric reading was taken at $540 \mathrm{~nm}$ using $\mathrm{KNO}_{3}(10,25,50$, 100, 150, 200 and $250 \mathrm{mmol} \mathrm{L}^{-1} \mathrm{NO}_{3}^{-}$) as standard. Readings were taken on microplate spectrophotometer (ThermoFisher Scientific) using 96-well microplates. The results were used to construct depletion curves of these ions during the period analyzed.

The plants were then harvested and separated into leaf blades, petiole, stem and root, and the fresh mass and root volume were determined. Samples of fresh material of each plant part, weighing $0.5 \mathrm{~g}$, were separated and stored in ethanol (80\%), and after the alcoholic extraction, chloroform partitioning was carried out. The extracts obtained were analyzed to measure the following soluble fractions: free amino-N (YEMM; COCKING, 1955), N-

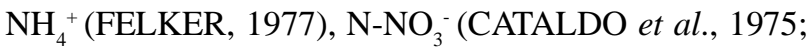
MIRANDA; ESPEY; WINK, 2001), with modifications described previously and soluble sugars (YEMM; 
WILLIS, 1954). The remaining plant material was dried, ground and used to measure the total nitrogen content (TEDESCO et al., 1995).

\section{RESULTS AND DISCUSSION}

When the plants were submitted to $0.2 \mathrm{mmol} \mathrm{L}^{-1}$ of $\mathrm{NO}_{3}^{-}$, the $\mathrm{pH}$ declined over time (Figure 1A), but with $2.0 \mathrm{mmol} \mathrm{L}^{-1}$ the $\mathrm{pH}$ increased until about 26 hours after application of the treatment, after which it gradually fell (Figure 1B). The ammonium nutrition promoted a gradual increase in the acidity of the nutritive solution in both treatments (Figures $1 \mathrm{~A}$ and $1 \mathrm{~B}$ ). Increased acidity of the solution was also observed by (SILVA; COUTO; SANTOS, 2010), who reported a reduction of the nutritive solution's $\mathrm{pH}$ with time when studying sunflower nutrition.

The plants grown with $\mathrm{NH}_{4}^{+}$in general presented higher $\mathrm{V}_{\max }$ values than those cultivated with $\mathrm{NO}_{3}^{-}$. This can be explained by the fact that $\mathrm{NH}_{4}^{+}$is quickly assimilated in the cytosol, or it can be an indication that this genotype contains a larger number of $\mathrm{NH}_{4}^{+}$carriers in the roots (Table 1).

The plants cultivated with $0.2 \mathrm{mmol} \mathrm{L}^{-1}$ of $\mathrm{NO}_{3}^{-}$or $\mathrm{NH}_{4}^{+}$presented similar root volumes. However, the root volume of the plants supplied with $2.0 \mathrm{mmol} \mathrm{L}^{-1}$ of $\mathrm{NO}_{3}^{-}$was greater than that of the plants given the same concentration

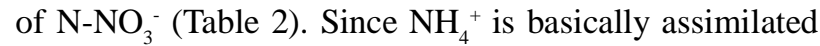
in the roots, the plants use insoluble carbohydrates from the roots, causing a reduction in the root system's biomass (BORGES et al., 2009). Cometti et al. (2004), working with lettuce plants grown hydroponically, also found lower biomass of the roots with supply of ammonium nutrition. The root/aerial part ratio reflects the plant's capacity to develop the root system in relation to the aerial part. In this respect, the plants supplied with a high ammonium dose presented a lower root/aerial part ratio, a finding that corroborates the observation of Rocha (2013). The architecture and morphology of the root system is influenced by the forms of available $\mathrm{N}$, and

Figure 1 - Effect of concentration of $0.2 \mathrm{mmol} \mathrm{L}^{-1}$ of $\mathrm{NO}_{3}^{-}$or $\mathrm{NH}_{4}^{+}(\mathrm{A})$ and of $2.0 \mathrm{mmol} \mathrm{L}^{-1}$ of $\mathrm{NO}_{3}^{-}$or $\mathrm{NH}_{4}^{+}$(B) on the temporal $\mathrm{pH}$ variation of the nutritive solution for sunflower plants
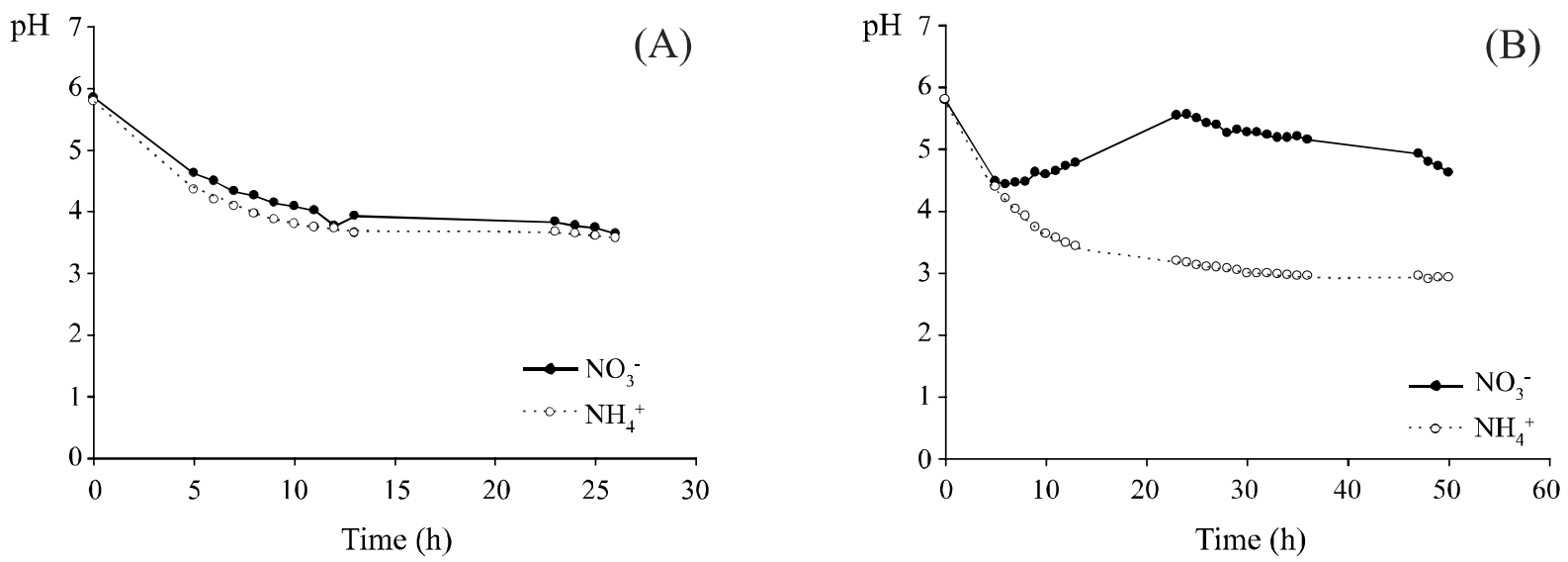

Table 1 - Kinetics parameters of Neon hybrid sunflower plants grown with different concentrations $\left(0.2\right.$ and $\left.2.0 \mathrm{mmol} \mathrm{L}^{-1}\right)$ and sources $\left(\mathrm{N}-\mathrm{NO}_{3}^{-}\right.$e $\left.\mathrm{N}-\mathrm{NH}_{4}^{+}\right)$of $\mathrm{N}$

\begin{tabular}{llc}
\hline \multicolumn{1}{c}{ Treatments } & Kinetics parameters \\
\hline $0.2 \mathrm{mmol} \mathrm{L}^{-1}$ & $\left.\mathrm{~K}_{m}(\mu \mathrm{mol} \mathrm{L})^{-1}\right)$ & $\mathrm{V}_{\max }\left(\mu \mathrm{mol} \mathrm{g}^{-1} \mathrm{~h}^{-1}\right)$ \\
$\mathrm{NO}_{3}^{-}$ & $48.90 \mathrm{a}$ & $6.40 \mathrm{~b}$ \\
$\mathrm{NH}_{4}^{+}$ & $48.47 \mathrm{a}$ & $106.06 \mathrm{a}$ \\
\hline $2.0 \mathrm{mmol} \mathrm{L}^{-1}$ & $\mathrm{~K}_{m}\left(\mu \mathrm{mol} \mathrm{L}^{-1}\right)$ & $\mathrm{V}_{\max }\left(\mu \mathrm{mol} \mathrm{g}^{\left.-1 \mathrm{~h}^{-1}\right)}\right.$ \\
$\mathrm{NO}_{3}^{-}$ & $228.74 \mathrm{~b}$ & $54.75 \mathrm{~b}$ \\
$\mathrm{NH}_{4}^{+}$ & $922.71 \mathrm{a}$ & $212.71 \mathrm{a}$ \\
\hline
\end{tabular}

*Equal letters in the line do not differ between each other at $5 \%$ probability by the Tukey test 


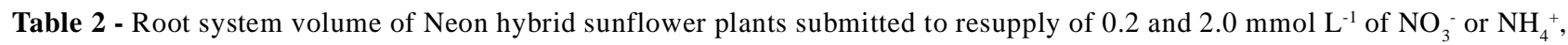
after $\mathrm{N}$ deprivation for $72 \mathrm{~h}$

\begin{tabular}{ccc}
\hline & \multicolumn{2}{c}{ Root volume $\left(\mathrm{cm}^{3}\right)$} \\
\hline Dose of $\mathrm{N}\left(\mathrm{mmol} \mathrm{L}^{-1}\right)$ & $\mathrm{NO}_{3}^{-}$ & $\mathrm{NH}_{4}^{+}$ \\
\cline { 2 - 3 } & $64.50 \mathrm{a}$ source & $62.59 \mathrm{a}$ \\
2.0 & $70.75 \mathrm{a}$ & $40.82 \mathrm{~b}$ \\
\hline
\end{tabular}

*Equal letters in the line do not differ between each other at $5 \%$ probability by the Tukey test

nitrate promotes elongation of the roots, while ammonium mainly stimulates the emergence of lateral roots (XU; FAN; MILLER, 2012).

In comparing the treatments with high dose of $\mathrm{N}$, the plants grown with $\mathrm{NH}_{4}^{+}$presented a higher $\mathrm{V}_{\max }$ value (Table 1) and also a lower root/aerial part ratio (Table 3), suggesting the existence of more sites for uptake of this ion.

The application of the highest $\mathrm{N}_{-} \mathrm{NO}_{3}^{-}$rate $\left(2.0 \mathrm{mmol} \mathrm{L}^{-1}\right)$ resulted in a significant increase in the fresh mass yield of the leaves when compared with the lowest dose (Table 3). This difference can be explained by the fact that with low supply of $\mathrm{N}$ $\mathrm{NO}_{3}^{-}$, there is low utilization of carbon skeletons (C), directly affecting the production of biomass. Brito et al. (2013), working with crambe (Abyssinian kale) in a hydroponic system, also observed this increase in biomass of the leaves when the plants were supplied with $2.0 \mathrm{mmol} \mathrm{L}^{-1}$ of $\mathrm{N}_{-} \mathrm{NO}_{3}$.

In the treatments with low dose, from both sources, there was no significant difference in biomass of the different plant compartments (Table 3). These results indicate there is no source preference when the $\mathrm{N}$ supply is low.

Analyzed together, the data on root volume and fresh mass accumulation indicate that resupply of $2.0 \mathrm{mmol} \mathrm{L}^{-1}$ of $\mathrm{NO}_{3}^{-}$is the most efficient way of providing $\mathrm{N}$ under the conditions of this experiment. In general in relation to the treatments, the plants preferentially accumulated $\mathrm{N}$ in the leaves (Table 4).

The treatment with $2.0 \mathrm{mmol} \mathrm{L}^{-1}$ of $\mathrm{NO}_{3}^{-}$led to the highest $\mathrm{N}$ concentrations in all four plant parts (Table 3), possibly because of the greater biomass yield, as shown by the values of root volume (Table 2) and fresh mass (Table 3), demonstrating better development when submitted to this treatment.

Higher concentrations of $\mathrm{N}_{-} \mathrm{NO}_{3}^{-}$were found in the petiole when the plants were submitted to the treatment with the lowest nutrient level, with both $\mathrm{N}$ sources, suggesting that the petiole is a preferential organ for storing $\mathrm{N}^{-\mathrm{NO}_{3}}$ (Figure 2a). Rocha et al. (2014), also studying sunflower plants in a hydroponic system, found the stem to be the compartment with highest storage of $\mathrm{NO}_{3}^{-}$. However, in that study the author did not analyze the quantity of the nutrient in the petioles. Santos et al. (2009) concluded that in rice, flag leaf and leaf 2 act as preferential sites of $\mathrm{N}$ storage. Concentration analysis of $\mathrm{N}^{-\mathrm{NO}_{3}}{ }^{-}$per pot (Figure $3 \mathrm{a}, 4 \mathrm{~b}$ ) showed a reduction of the dilution effect and allows stating that the petiole really was the main organ for storing $\mathrm{N}$, for both forms of the nutrient, when supplied at a dose of $0.2 \mathrm{mmol} \mathrm{L} \mathrm{L}^{-1}$. Thus, petiole seems act as reserve organ for sunflower plant, suggesting greater potential for translocation of $\mathrm{N}$ stored in these tissues.

Table 3 - Fresh mass (g per 2 plants) of sunflower plants (Neon hybrid) submitted to resupply of 0.2 and $2.0 \mathrm{mmol} \mathrm{L}^{-1}$ of $\mathrm{NO}_{3}^{-}$or $\mathrm{NH}_{4}^{+}$, after $\mathrm{N}$ deprivation for $72 \mathrm{~h}$

\begin{tabular}{lclcccc}
\hline \multicolumn{7}{c}{ Resupply of 0.2 mmol L-1 } \\
\hline \multicolumn{1}{c}{ Treatments } & Leaf blades & Petiole & Stem & Roots & Shoot & Root / Shoot \\
\hline $\mathrm{NO}_{3}^{-}$ & $48.40 \mathrm{a}$ & $20.89 \mathrm{a}$ & $29.53 \mathrm{a}$ & $37.80 \mathrm{a}$ & $91.47 \mathrm{a}$ & $0.42 \mathrm{a}$ \\
$\mathrm{NH}_{4}^{+}$ & $42.96 \mathrm{a}$ & $20.09 \mathrm{a}$ & $26.99 \mathrm{a}$ & $35.07 \mathrm{a}$ & $90.05 \mathrm{a}$ & $0.36 \mathrm{a}$ \\
\hline \multicolumn{7}{c}{ Resupply of $2.0 \mathrm{mmol} \mathrm{L}^{-1}$} \\
\hline $\mathrm{NO}_{3}^{-}$ & $54.28 \mathrm{a}$ & $28.01 \mathrm{a}$ & $36.58 \mathrm{a}$ & $43.62 \mathrm{a}$ & $118.89 \mathrm{a}$ & $0.36 \mathrm{a}$ \\
$\mathrm{NH}_{4}^{+}$ & $44.00 \mathrm{~b}$ & $19.14 \mathrm{~b}$ & $27.46 \mathrm{a}$ & $25.02 \mathrm{~b}$ & $90.60 \mathrm{~b}$ & $0.27 \mathrm{~b}$ \\
\hline
\end{tabular}

*Equal letters in the column do not differ between each other at $5 \%$ probability by the Tukey test 
Table 4 - Total $\mathrm{N}$ and $\mathrm{N}$ content in the leaves, petioles, stems and roots of Neon hybrid sunflower plants

\begin{tabular}{|c|c|c|c|c|}
\hline \multicolumn{5}{|c|}{ Total-N (mmoles per g dry matter) } \\
\hline Treatments & Leaf blades & Petioles & Stems & Roots \\
\hline $0.2 \mathrm{mmol} \mathrm{L}^{-1}$ of $\mathrm{NO}_{3}^{-}$ & $2.34 \mathrm{Aa}$ & $0.54 \mathrm{Ca}$ & $0.50 \mathrm{Ca}$ & $1.66 \mathrm{Ba}$ \\
\hline $0.2 \mathrm{mmol} \mathrm{L}^{-1}$ of $\mathrm{NH}_{4}+$ & $2.29 \mathrm{Aa}$ & $0.59 \mathrm{Ca}$ & $0.66 \mathrm{Ca}$ & $1.56 \mathrm{Ba}$ \\
\hline $2.0 \mathrm{mmol} \mathrm{L}^{-1}$ of $\mathrm{NO}_{3}^{-}$ & $2.58 \mathrm{Aa}$ & $0.66 \mathrm{Ca}$ & $0.81 \mathrm{Ca}$ & $1.94 \mathrm{Ba}$ \\
\hline $2.0 \mathrm{mmol} \mathrm{L}^{-1}$ of $\mathrm{NH}_{4}+$ & $1.17 \mathrm{Bb}$ & $0.16 \mathrm{Cb}$ & $0.56 \mathrm{Ca}$ & $2.09 \mathrm{Aa}$ \\
\hline \multicolumn{5}{|c|}{$\mathrm{N}$ content (mg per plant) } \\
\hline $0.2 \mathrm{mmol} \mathrm{L}^{-1}$ of $\mathrm{NO}_{3}^{-}$ & $176.91 \mathrm{Aa}$ & $10.73 \mathrm{Ca}$ & $25.92 \mathrm{BCa}$ & $57.64 \mathrm{Ba}$ \\
\hline $0.2 \mathrm{mmol} \mathrm{L}^{-1}$ of $\mathrm{NH}_{4}^{+}$ & $157.49 \mathrm{Aa}$ & $10.54 \mathrm{Ba}$ & $25.67 \mathrm{Ba}$ & $44.31 \mathrm{Ba}$ \\
\hline $2.0 \mathrm{mmol} \mathrm{L}^{-1}$ of $\mathrm{NO}_{3}^{-}$ & $228.20 \mathrm{Aa}$ & $15.61 \mathrm{Ca}$ & $41.07 \mathrm{BCa}$ & $70.15 \mathrm{Ba}$ \\
\hline $2.0 \mathrm{mmol} \mathrm{L}^{-1}$ of $\mathrm{NH}_{4}^{+}$ & $62.69 \mathrm{Ab}$ & $2.61 \mathrm{Ba}$ & $20.87 \mathrm{Aba}$ & $39.34 \mathrm{Aba}$ \\
\hline
\end{tabular}

*Equal letters lowercase in the column and uppercase letter in the line do not differ between each other at $5 \%$ probability by the Tukey test

According Crawford and Glass et al. (1998), excess of nitrate uptake by the plant can be stored in the vacuole serving as mineral nitrogen source when the supply from the soil becomes. In maize, the yield increase in genotypes was due to their ability to accumulate $\mathrm{NO}_{3}^{-}$in their leaves during vegetative growth and its efficient remobilization during the grain filling (HIREL et al., 2001).

In the plants provided with resupply of the highest $\mathrm{NO}_{3}^{-}$rate, the greatest level of this nutrient was found in the roots, while at the highest dose of $\mathrm{NH}_{4}^{+}$the greatest concentration was in the petiole (Figure 2b).

In the plants grown with $\mathrm{NH}_{4}^{+}$as the only $\mathrm{N}$ source, in both treatments, concentrations of $\mathrm{NO}_{3}^{-}$were surprisingly found in the tissues (Figures 2a, 2b, 3a, 3b), possibly due to the fact that plants were grown with $\mathrm{NO}_{3}$ and $\mathrm{NH}_{4}^{+}$before the $\mathrm{N}$ deprivation step. Therefore, the time during which the plants were deprived of $\mathrm{N}$ may not have been long enough for complete exhaustion of the $\mathrm{NO}_{3}^{-}$from the "reserve pool" stored in the vacuoles for subsequent remobilization.

In the treatments with $0.2 \mathrm{mmol} \mathrm{L}^{-1}$ of $\mathrm{NO}_{3}^{-}$and $\mathrm{NH}_{4}^{+}$, concentrations of $\mathrm{N}-\mathrm{NH}_{4}{ }^{+}$were only found in the roots of the plants cultivated with com $\mathrm{N}^{-\mathrm{NO}_{3}}{ }^{-}$(Figure 2c), because at a low dose of $\mathrm{N}-\mathrm{NH}_{4}{ }^{+}$, the nutrient taken up by the roots was quickly assimilated. On the other hand, the appearance of concentrations of $\mathrm{N}_{-} \mathrm{NH}_{4}{ }^{+}$only in the roots (Figures 2c and 2d) can also be explained by the greater capacity to assimilate this ion in the aerial part in function of the greater availability of carbon skeletons (Figures $2 \mathrm{~g}$ and $2 \mathrm{~h}$ ) from photosynthesis.

The resupply with $2 \mathrm{mmol} \mathrm{L}^{-1}$ of $\mathrm{NO}_{3}^{-}$and $\mathrm{NH}_{4}^{+}$ caused accumulation of $\mathrm{N}^{-\mathrm{NH}_{4}}{ }^{+}$in the roots, although the same was not observed in the aerial parts (Figures $2 \mathrm{~d}$ and $3 \mathrm{~d}$ ). The assimilation of $\mathrm{NH}_{4}^{+}$occurs basically in the roots, due to its toxicity to the plant, so the nutrient tends to be quickly assimilated (SOUZA; FERNANDES, 2006).

When plants were submitted to high doses of both $\mathrm{NO}_{3}{ }^{-}$and $\mathrm{NH}_{4}^{+}$, there was an increase of $\mathrm{N}$-amino levels in the tissues, except for the petioles, in which the concentration declined (Figure 2f). The fact that the petioles presented lower concentrations of $\mathrm{N}$-amino can indicate lower assimilation of the nutrient in this compartment (Figures 2f, 3e and 3f). It was observed that when there is $\mathrm{NO}_{3}^{-}$reduction or remobilization from roots or shoots occurs free amino-N production in such compartments (Figure 3). The same was observed by Santos et al. (2007) in rice plants grown under nitrate fertilizer.

The treatment with the high dose of $\mathrm{NH}_{4}^{+}$ compared with the high dose of $\mathrm{NO}_{3}^{-}$produced a greater concentration of $\mathrm{N}$-amino in the roots (Figure 2f). This can be explained by the fact that $\mathrm{NH}_{4}{ }^{+}$needs to be rapidly assimilated, which occurs preferentially in the roots. Sperandio et al. (2011) also observed a greater concentration of $\mathrm{N}$-amino in the roots of rice plants grown with $\mathrm{NH}_{4}^{+}$compared to plants supplied with $\mathrm{NO}_{3}^{-}$.

The stem was the compartment containing the highest levels of soluble sugars, followed by the petiole, in all the treatments (Figures $2 \mathrm{~g}$ and $2 \mathrm{~h}$ ). These results indicate that the Neon hybrid might have better potential for storing $\mathrm{N}$ in these compartments. In analyzing the concentration of soluble sugars, the stem stood out from the other compartments by presenting 
Figure 2 - Concentrations of $\mathrm{N}^{-\mathrm{NO}_{3}}{ }^{-}(\mathrm{a}, \mathrm{b}), \mathrm{N}^{-\mathrm{NH}_{4}}{ }^{+}(\mathrm{c}, \mathrm{d})$, free $\mathrm{N}$-amino $(\mathrm{e}, \mathrm{f})$ and soluble sugars $(\mathrm{g}, \mathrm{h})$ in different parts of sunflower plants of the Neon hybrid submitted to resupply of 0.2 and $2.0 \mathrm{mmol} \mathrm{L}^{-1}$ of $\mathrm{NO}_{3}^{-}$or $\mathrm{NH}_{4}^{+}$, after $\mathrm{N}$ deprivation for $72 \mathrm{~h}$. The bars represent the mean standard error of the repetitions
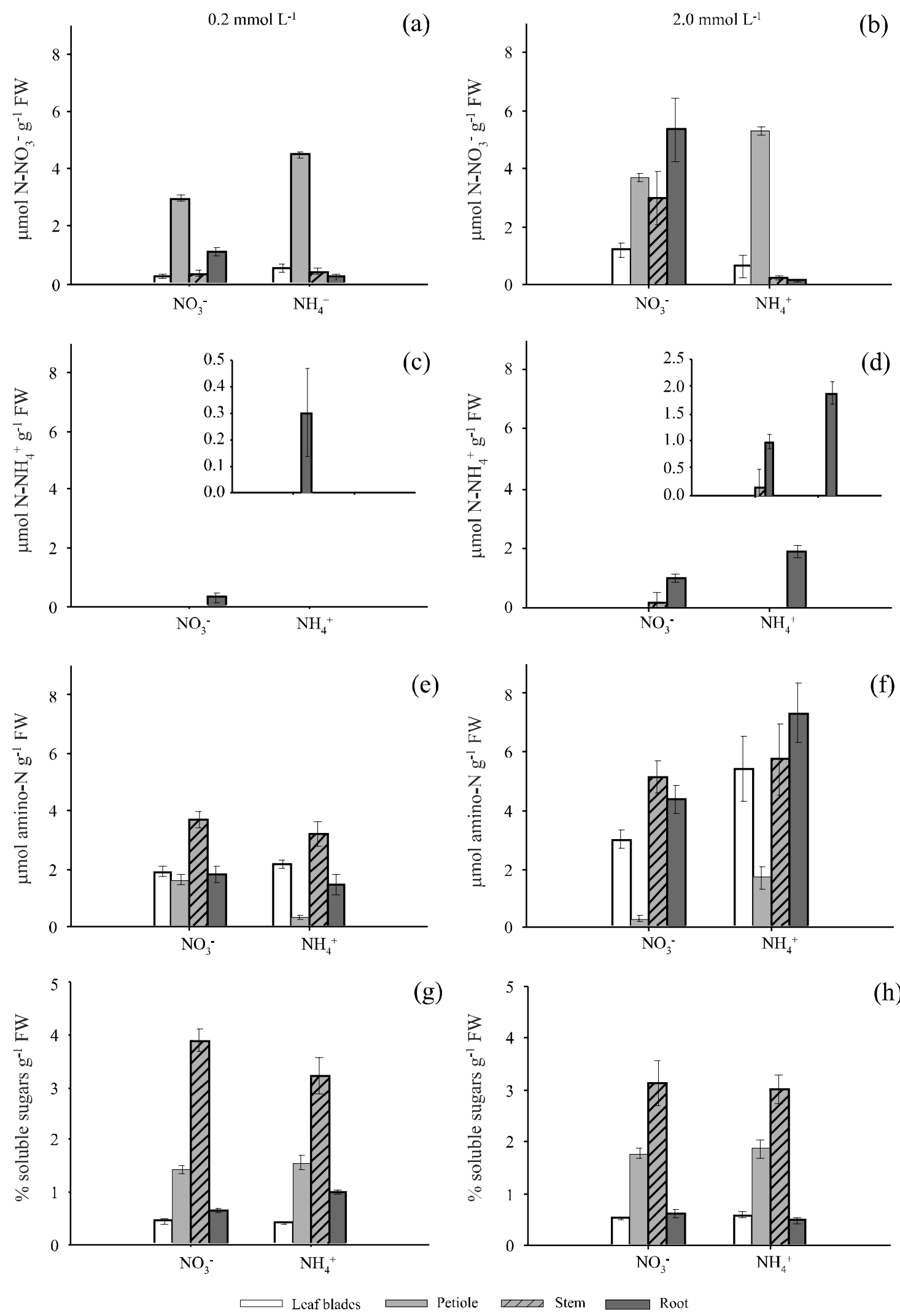
Figure 3 - Content (g per pot) of $\mathrm{N}_{-} \mathrm{NO}_{3}^{-}(\mathrm{a}, \mathrm{b}), \mathrm{N}^{-\mathrm{NH}_{4}}{ }^{+}(\mathrm{c}, \mathrm{d})$, free $\mathrm{N}$-amino $(\mathrm{e}, \mathrm{f})$ and soluble sugars $(\mathrm{g}, \mathrm{h})$ in different parts of sunflower plants of the Neon hybrid submitted to resupply of 0.2 and $2.0 \mathrm{mmol} \mathrm{L}^{-1}$ of $\mathrm{NO}_{3}^{-}$or $^{-\mathrm{NH}_{4}^{+}}$, after $\mathrm{N}$ deprivation for $72 \mathrm{~h}$. The bars represent the mean standard error of the repetitions
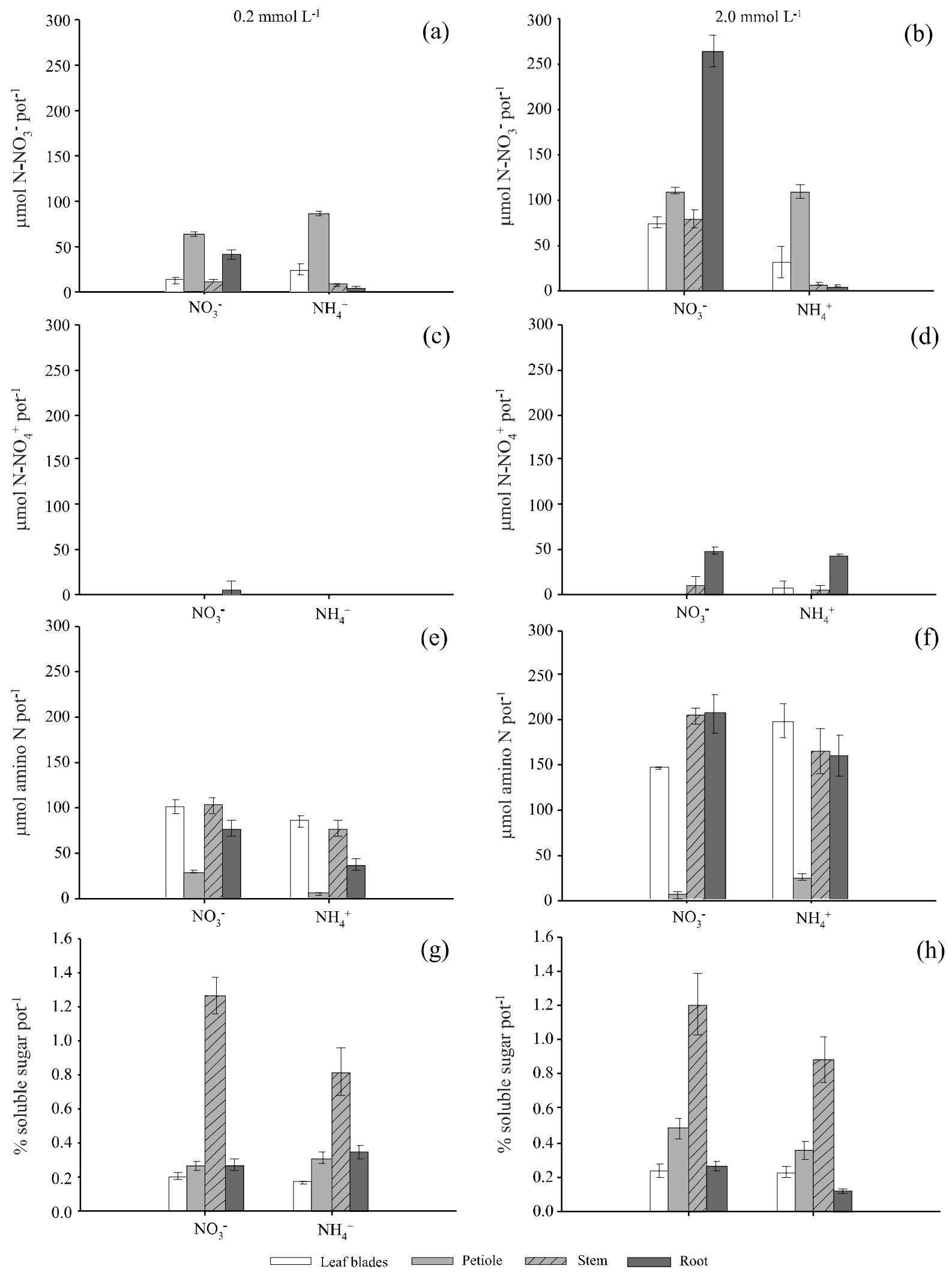

Rev. Ciênc. Agron., v. 47, n. 1, p. 13-21, jan-mar, 2016 
higher values, so this region appears to be the main one for accumulation of sugars (Figures $3 \mathrm{~g}$ and $3 \mathrm{~h}$ ). Rocha et al. (2014) also found the stem to be the place of greatest accumulation of sugars in the sunflower BRS324 variety cultivated in a hydroponic system.

\section{CONCLUSIONS}

1. The Neon sunflower genotype, when grown with $\mathrm{N}$ $\mathrm{NH}_{4}^{+}$, presented higher $\mathrm{V}_{\text {max }}$ in comparison with the plants supplied with $\mathrm{N}_{-} \mathrm{NO}_{3}^{-}$;

2. Although presenting the lowest $\mathrm{V}_{\max }$ value, the plants supplied with $2.0 \mathrm{mmol} \mathrm{L}{ }^{-1}$ of $\mathrm{N}_{-} \mathrm{NO}_{3}^{-}$presented higher biomass than those supplied with the same dose of $\mathrm{N}$ $\mathrm{NH}_{4}^{+}$, which can indicate a greater potential for use of nitric $\mathrm{N}$;

3. There was no difference in accumulation of biomass in the plants grown with the lowest $\mathrm{N}$ dose $(0.2 \mathrm{mmol} \mathrm{L}$ $\left.{ }^{1}\right)$, suggesting that in the conditions of this experiment, there is no preference for the $\mathrm{N}$ source;

4. The petiole is the preferential organ for accumulation of $\mathrm{N}^{-\mathrm{NO}_{3}}$.

\section{REFERENCES}

ASLAM, M.; TRAVIS, R. L.; HUFFAKER, R. C. Comparative induction of nitrate and nitrite uptake and reduction systems by ambient nitrate and nitrite in intact roots of barley (Hordeum vulgare L.) seedlings. Plant physiology, v. 102, n. 3, p. 811-819, 1993.

BORGES, E. D. A. et al. Cinética de absorção de amônio e efluxo de prótons em variedades de milho. Semina: Ciências Agrárias, v. 30, n. 3, p. 513-526, 2009.

BRITO, D. D. M. C. de. et al. Effects of nitrate supply on plant growth, nitrogen, phosphorus and potassium accumulation, and nitrate reductase activity in crambe. Journal of Plant Nutrition, v. 36 , n. 2, p. $275-283,2013$

CATALDO, D. A. et al. Rapid colorimetric determination of nitrate in plant tissue by nitration of salicylic acid. Communications in Soil Science and Plant Analysis, v. 6, n. 1, p. 71-80, jan. 1975.

COMETTI, N. N. et al. Compostos nitrogenados e açúcares solúveis em tecidos de alface orgânica, hidropônica e convencional. Horticultura Brasileira, v. 22, n. 4, p. 748753, 2004.

CRAWFORD, N. M.; GLASS, A. D. M. Molecular and physiological aspects of nitrate uptake in plants. Trends in Plant Science, v. 3, n. 10, p. 389-395, 1998.
FELKER, P. Microdetermination of nitrogen in seed protein extracts with the salicylate-dichloroisocyanurate color reaction. Analytical Chemistry, v. 49, n. 7, p. 1080, 1977.

FERNÁNDEZ-MARTÍNEZ， J. M.; PÉREZ-VICH， B.; VELASCO L. Sunflower. In: VOLLMANN, J.; RAJCAN, I. Oil Crops. New York: Ed. Springer Science Business Media,2009. p. 155-232. (Handbook of Plant Breeding, v. 4)

HIREL, B. et al. Towards a better understanding of the genetic and physiological basis for nitrogen use efficiency in maize. Plant Physiology, v. 125, p. 1258-1270, 2001.

HOAGLAND, D. R.; ARNON, D. I. The water-culture method for growing plants without soil. California Agricultural Experiment Station, p. 1-32, 1950.

MARSCHNER, P.(Ed.) Marschner's mineral nutrition of higher plants. 3rd. ed. London: Academic Press: Elsevier, 2012, 643 p.

MIRANDA, K. M.; ESPEY, M. G.; WINK, D. A. A rapid, simple spectrophotometric method for simultaneous detection of nitrate and nitrite. Nitric oxide: biology and chemistry: official journal of the Nitric Oxide Society, v. 5, n. 1, p. 6271, fev. 2001.

OKAMOTO, M. et al. High-affinity nitrate transport in roots of arabidopsis depends on expression of the NAR2-Like Gene AtNRT3.1. Plant Physiology, v. 140, n. 3, p. 1036-1046, 2006.

ROCHA, J. G. da. et al. Cinética de absorção de nitrogênio e acúmulo de frações solúveis nitrogenadas e açúcares em girassol. Pesquisa Agropecuária Tropical, v. 44, n. 4, p. 381390, 2014.

ROCHA, J. G. Produção de óleo e avaliações metabólicas em genótipos de girassol (Helianthus annuus L.) sob diferentes manejos e doses de nitrogênio. 2013. 101 f. Dissertação (Mestrado em Agronomia). - Universidade Federal Rural do Rio de Janeiro, Rio de Janeiro, 2013.

SANTOS, A. M. et al. Efeito da disponibilidade de nitrato em solução nutritiva sobre a absorção de nitrogênio e atividade enzimática de duas cultivares de arroz. Bragantia, v. 68 , n. 1, p. 53-61, 2009.

SANTOS, A. M. et al. Effects of seasonal nitrate flush on nitrogen metabolism and soluble fractions accumulation in two rice varieties. Journal of Plant Nutrition, v. 30, n. 9, p. 13711384, 2007

SOUZA, S. R.; FERNANDES, M. S. Nitrogênio. In: FERNANDES, M. S. Nutrição mineral de plantas. Viçosa, MG: Sociedade Brasileira de Ciência do Solo, 2006. p. 215-252.

SIDDIQI, M. Y. et al. Studies of the uptake of nitrate in barley. I. Kinetics of ${ }^{13} \mathrm{NO}_{3}^{-}$Influx. Plant Physiology, v. 93, p. 14261432,1990

SILVA, P. C. C.; COUTO, J. L. do; SANTOS, A. R. do. Efeito dos íons amônio e nitrato no desenvolvimento do girassol em solução nutritiva. Revista da FZVA, v. 17, n. 3, p. 104-114, 2010. 
SPERANDIO, M. V. L. et al. Isoforms of plasma membrane $\mathrm{H}(+)$-ATPase in rice root and shoot are differentially induced by starvation and resupply of $\mathrm{NO}_{3}{ }^{-}$or $\mathrm{NH}_{4}^{+}$. Plant Science, v. 180, n. 2, p. 251-258, 2011.

TEDESCO, J. M. et al. Análise de solo, plantas e outros materiais. 2. ed. Porto Alegre: UFRGS, 1995. 174 p.

XU, G.; FAN, X.; MILLER, A. J. Plant nitrogen assimilation and use efficiency. Annual Review of Plant Biology, v. 63, p. 153-82, 2012.
YEMM, E. W.; COCKING, E. C. The determination of aminoacid with ninhydrin. Analytical Biochemistry, v. 80, p. 209213, 1955. YEMM, E. W.; WILLIS, A. J. The Estimation of carbohydrates in plant extracts by anthrone. Biochemical Journal, v. 54, p. 508-514, 1954.

ZAGONEL, J.; MUNDSTOCK, C. M. Doses e épocas de aplicação de nitrogênio em cobertura em duas cultivares de girassol. Pesquisa Agropecuária Brasileira, v. 26, n. 9, p. 14871492, 1991. 